Jurnal

Kardiologi Indonesia

J Kardiol Indones. 2015;36:162-7

ISSN 0I26/3773

\title{
Metabolism changes and the role of the free radicals on myocardial ischemia
}

Dyana Sarvasti

Departemen Ilmu Penyakit Dalam, Fakultas Kedokteran Universitas Katolik Widya Mandala, Surabaya, RS Husada Utama, Surabaya
Myocardial ischemic results from severe impairment of coronary blood supply and produces a spectrum of clinical syndromes. It results in a characteristic pattern of metabolic and structural changes that leads to extremely complex situations, which have been extensively studied in recent years. A detailed understanding is now available of the complexity of the response of the myocardium to an ischemic insult. Reperfusion is the most effective way to treat the ischaemic myocardial. But, restoration of flow, however, might result in numerous other negative consequences, thus directly influencing the degree of recovery. Much evidence shows that during the period of myocardial ischemia and reperfusion can occur various changes both in terms of metabolic, electrical, histology, structural, and physiological. Pathological changes in the form of metabolic changes and the role of free radicals on the condition of ischemia and reperfusion injury will be discussed. There are several potential manifestations and outcomes associated with myocardial ischemia and reperfusion.

(J Kardiol Indones. 2015;36:162-7)

Keywords: Myocardial ischemia, myocardial reperfusion, metabolic changes, free radicals 


\title{
Perubahan metabolisme dan peran radikal bebas pada iskemia miokard
}

\author{
Dyana Sarvasti
}

\begin{abstract}
Iskemia miokard yang timbul akibat gangguan aliran darah koroner yang berat dapat menimbulkan suatu sindroma klinis. Iskemia menyebabkan perubahan metabolik dan struktural yang sangat kompleks, dan telah dipelajari secara ekstensif dalam beberapa tahun terakhir. Saat ini pemahaman mengenai kompleksitas respon miokardium terhadap kejadian iskemia secara rinci telah tersedia. Reperfusi adalah cara yang paling efektif untuk mengobati iskemia miokard. Tetapi, pemulihan aliran darah tersebut, dapat mengakibatkan berbagai konsekuensi negatif, sehingga secara langsung dapat mempengaruhi timbulnya tingkat pemulihan. Banyak bukti menunjukkan bahwa selama periode iskemia miokard dan reperfusi dapat terjadi berbagai perubahan baik dari segi metabolisme, listrik, histologi, struktural, dan fisiologis. Perubahan patologis dalam bentuk perubahan metabolik dan peran radikal bebas pada kondisi iskemia dan cedera reperfusi akan dibicarakan. Terdapat beberapa manifestasi dan hasil penting yang terkait dengan iskemia miokard dan reperfusi.
\end{abstract}

(J Kardiol Indones. 2015;36:162-7)

Kata kunci : Iskemia miokard, reperfusi miokard, radikal bebas, perubahan metabolik

\section{Pendahuluan}

I skemia miokard menggambarkan suatu kondisi ketika fraksi oksigen yang diserap oleh jantung tidak cukup untuk mempertahankan oksidasi tingkat seluler. ${ }^{1}$ Iskemia berasal dari bahasa Yunani isch, yang berarti hambatan; dan haema, yang berarti darah. ${ }^{2}$ Iskemia miokard dapat berkembang sebagai konsekuensi dari meningkatnya kebutuhan oksigen atau kekurangan suplai oksigen. ${ }^{3}$ Situasi ini menyebabkan kerusakan dan tidak

\footnotetext{
Alamat Korespondensi:

dr. Dyana Sarvasti, SpJP(K), Departemen Ilmu Penyakit Dalam, Fakultas Kedokteran Universitas Katolik Widya Mandala, Surabaya, RS Husada Utama, Surabaya. E-mail: dyana_sarvasti@yahoo.com
}

berfungsinya jaringan jantung yang sangat kompleks yang hingga kini masih terus dipelajari..$^{1,2}$

Pada tahun 1960, Jennings dan koleganya, pertama kali melakukan penelitian iskemia miokard menggunakan jantung anjing yang diligasi arteri koronernya. Dalam 8-10 detik, kondisi tersebut menyebabkan kebutuhan oksigen jaringan yang terkena dampak, meningkat melebihi suplai yang didapat dari aliran arteri kolateral, dan tekanan oksigen intramiokard turun drastis. Bertepatan dengan awal kondisi hipoksia, metabolisme energi berubah dari jalur aerobik menjadi glikolisis anaerobik. Jumlah fosfat energi tinggi (high-energy phosphate/HEP) yang dihasilkan oleh glikolisis anaerobik tidak cukup untuk mempertahankan kadar cadangan HEP jaringan, sehingga kadar kreatinin fosfat (creatine phosphate/CP) turun dengan cepat. Dalam hitungan detik kekuatan 
kontraksi sel-sel iskemik turun bermakna. Namun sel-sel tersebut tidak mati meskipun tidak dapat berkontraksi lagi. Jika aliran arteri koroner difungsikan kembali, maka dalam 15 menit sel-sel yang cedera mendapatkan kembali aktivitas listrik dan kemampuan mekaniknya. Periode tersebut disebut dengan fase cedera iskemia yang reversibel (reversible phase of ischemic injury). Sebaliknya, jika iskemia dibiarkan tetap terjadi, maka sel-sel yang terkena dampak akan mengalami kematian. Miosit jantung anjing dapat menoleransi iskemia low-flow (aliran arteri kolateral kurang dari 10-12\% aliran kontrol) hingga 18 menit, tetapi akan mati bila iskemia tersebut tetap terjadi dalam 40-60 menit. ${ }^{2,4}$

Reperfusi untuk mengembalikan suplai darah pada jaringan iskemik memerlukan tindakan intervensi, seperti trombolisis, percutaneous transluminal coronary angioplasty (PTCA) atau coronary artery bypass surgery (CABG). Reperfusi dapat merubah kondisi iskemia dan menyebabkan restorasi suplai oksigen dengan lengkap dan mengembalikan energi tinggi fosfat. ${ }^{3}$ Meskipun terapi reperfusi yang dilakukan dengan cepat telah terbukti dapat mengurangi angka kematian, ukuran infark, dan meningkatkan fungsi ventrikel kiri pada infark miokard dengan ST-elevasi (STEMI), namun masih didapatkan morbiditas dan mortalitas yang tersisa. Fenomena tersebut diberi istilah injuri reperfusi (reperfusion injury), yang menyebabkan kematian sel yang lethal. ${ }^{5}$

Banyak bukti menunjukkan bahwa selama periode iskemia miokard dapat terjadi berbagai perubahan baik dari segi metabolik, elektrik, histologi, struktural, dan fisiologis. ${ }^{6}$ Perubahan patologis berupa perubahan metabolik dan peran radikal bebas pada kondisi iskemia dan injuri reperfusi, akan dibahas lebih lanjut dalam tinjuan pustaka ini.

\section{Dampak Iskemia Miokard pada Metabolisme Sel}

Seperti sel-sel eukariotik aerobik lainnya, sel-sel pada manusia memerlukan oksigen untuk mempertahankan proses homeostasis. Hambatan aliran darah yang terjadi di jaringan menyebabkan suplai oksigen terganggu dan mengacaukan reaksi biokimia yang menjamin tetap berlangsungnya fungsi, integritas dan daya tahan sel-sel. ${ }^{7}$

Kondisi iskemia yang berat dan berlangsung lama menyebabkan perubahan-perubahan pada tingkat seluler. ${ }^{7}$ Terjadi perubahan metabolisme yang berkaitan dengan hambatan kontraksi (excitation-contraction uncoupling) dan perubahan sistem transpor ionik pada sarkolema dan membran organelar. Perubahan pertama berupa hilangnya $\mathrm{K}^{+}$intraselular karena terjadi peningkatan efflux ion. Meskipun mekanisme tersebut belum jelas, namun diketahui bahwa hal tersebut melibatkan aktivasi kanal adenosine-5'-triphospate (ATP)-dependent $\mathrm{K}^{+}$karena terdapat perubahan rasio ATP/ADP atau mekanisme untuk mengurangi beban osmotik. Perubahan awal yang juga terjadi adalah peningkatan $\mathrm{Mg}^{2+}$, diikuti dengan penurunan $\mathrm{Mg}^{2+}$ total. Ketika ATP menurun, maka $\mathrm{Na}^{+}, \mathrm{K}^{+}$-ATPase dihambat, sehingga $\mathrm{K}^{+}$hilang dan $\mathrm{Na}^{+}$meningkat lebih lanjut. Influx cairan ekstraseluler yang menyertai menyebabkan sel menjadi bengkak. ${ }^{8}$ Kekurangan oksigen juga menyebabkan penurunan $\mathrm{pH}$ dan akumulasi laktat pada miosit yang iskemik. ${ }^{9}$

Peningkatan awal $\mathrm{Ca}^{2+}$ sitosolik memicu aktivasi protease dan fosfolipase sehingga terjadi kerusakan sitoskeletal dan gangguan keseimbangan membran fosfolipid. Perubahan pada protein kontraktil miofibril menyebabkan penurunan sensitivitas terhadap $\mathrm{Ca}^{2+}$ sehingga terjadi gangguan kontraktilitas meskipun terjadi peningkatan $\mathrm{Ca}^{2+}$ sitosolik. ${ }^{8,9}$

Akumulasi kalsium dan perubahan metabolik lainnya mengakibatkan perubahan lemak termasuk peningkatan degradasi fosfolipid (PL) yang melepaskan asam lemak bebas (free fatty acid/FFA) dan lisofosfolipid (lysophospolipids/LPL) dan penurunan sintesis fosfolipid. Gangguan metabolisme asam lemak menyebabkan akumulasi berbagai jenis lemak, termasuk asil CoA rantai panjang dan asil karnitin yang bersama-sama dengan hasil degradasi fosfolipid, dapat masuk melalui membran dan merusak fungsi mereka, sehingga menyebabkan akumulasi lemak amphipathic yang menganggu kestabilan membran. Peroksidasi lemak dapat terjadi akibat serangan radikal bebas yang dihasilkan oleh pembentukan elektron berlebih ( $\left.\mathrm{e}^{-}\right)$ pada mitokondria yang kekurangan oksigen..$^{8,9}$

Semua gangguan metabolik tersebut merupakan kunci transisi kejadian yang melibatkan pembukaaan permeabilitas pori transisi mitokondria (mitochondrial permeability transition pore/mPTP) di membran bagian dalam mitokondria. Pembukaan mPTP menyebabkan hilangnya perbedaan potensial listrik melalui membran bagian dalam $(\Delta \Psi \mathrm{m})$ sehingga terjadi penghentian sintesa ATP, influx solut, dan pembengkakan mitokondria yang berat. Tahap cedera ireversibel (irreversible phase of injury) dimediasi oleh keparahan kerusakan membran yang dihasilkan oleh hilangnya 
Sarvasti D: Perubahan metabolisme dan peran radikal bebas pada iskemia miokard

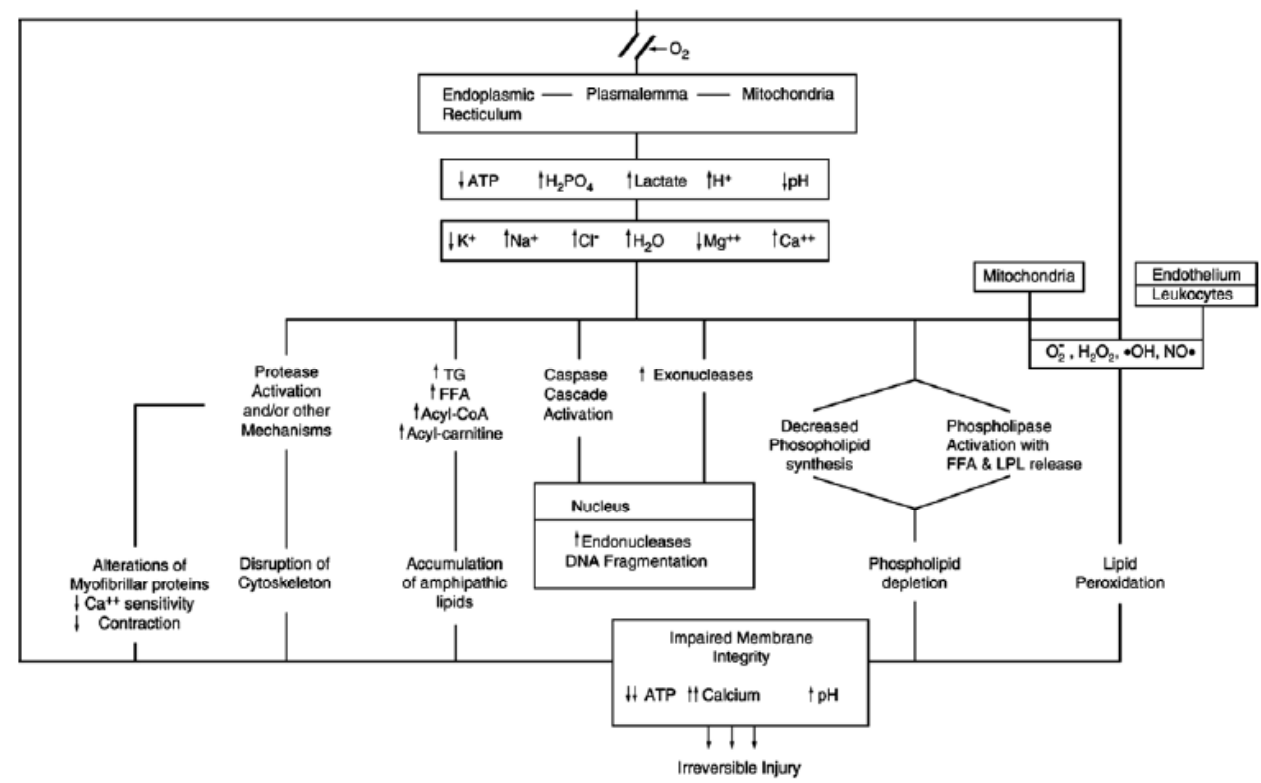

Gambar 1. Patogenesis iskemia miokard dan injuri reperfusi. Gambar dikutip dari. ${ }^{8}$

fosfolipid, peroksidasi lipid, dan kerusakan sitoskeletal (gambar 1). ${ }^{8,9}$

Sintesis protein merupakan proses kompleks yang memerlukan asupan energi yang terus menerus dan memadai, kontrol ketat homeostasis ion sel dan kelancaran fungsi banyak protein lainnya. Kondisi iskemia menyebabkan proses tersebut terganggu, sehingga sintesis protein ikut terganggu. Disebutkan bahwa transkripsi beberapa gen sebenarnya dimulai pada saat timbulnya iskemia, tetapi mekanisme yang mendasarinya belum sepenuhnya dipahami. Dalam hal tersebut, produksi massal radikal bebas, tingginya konsentrasi kalsium, asidosis dan aktivasi keluarga protein mitogen-activated protein kinases (MAP kinases) dianggap ikut berperan penting. Faktor nukleus heat shock transcription factor-1 (HSF-1) mengaktifkan ekspresi heat shock protein (Hsp), keluarga pendamping (chaperone) protein, dan menghambat ekspresi protein lainnya. Hsp disintesis pada situasi stres, termasuk hipertermia, iskemia, hipoksia, dan stres mekanik, yang dimaksudkan untuk mencegah modifikasi struktural metabolik utama dan enzim sitoskeletal, serta menghambat aktivitas caspase. Tekanan parsial oksigen yang rendah selama iskemia mengaktifkan faktor nukleus lainnya, seperti hypoxia-inducible factorlalpha (HIF-1 $\alpha$ ). HIF-1 $\alpha$ merangsang transkripsi banyak gen yang terlibat dalam pertahanan seluler, seperti yang melakukan encoding NOS (Nitrous Oxide
System) dan GLUT-1 (glucose transporter-1), dan enzim lainnya yang terlibat dalam metabolisme glukosa. Selain itu, iskemia mengaktifkan kekebalan bawaan dengan merangsang reseptor sarkoplasma, seperti Toll-like receptors (TLR), TLR-2 dan TLR-6, sehingga sintesis dan ekspresi sarkoplasma meningkat. Stimulasi reseptor mendukung sintesis kemokin dan sitokin dan berkontribusi pada kondisi iskemia injuri reperfusi. ${ }^{8}$

Pada awal iskemia, banyak zat yang disekresikan oleh sel. Sebagai contoh, iskemik kardiomiosit mengeluarkan bradikinin, norepinefrin, angiotensin, adenosin, asetilkolin dan opioid. ${ }^{10}$ Iskemia juga merangsang ekspresi molekul adhesi, seperti P-selektin, L-selektin, intercellular adhesion molecule-1 (ICAM-1) dan platelet-endothelial cell adhesion molecules (PECAM), pada permukaan sel endotel, leukosit dan sel iskemik lainnya. Selain itu, banyak sitokin, seperti tumor necrosis factor-, interleukin (IL) -1, IL-6 dan IL-8, dan agen vasoaktif, seperti endotelin dan tromboksan A2, yang disekresikan oleh sel-sel sebagai respon terhadap iskemia. Produksi sitokin dan kemokin meningkat secara dramatis selama reperfusi, sehingga respon inflamasi lokal dimulai dan sel inflamasi dikerahkan ke dalam daerah luka. ${ }^{8}$ Selama periode no-flow ischemia, sel-sel miosit secara metabolik masih mampu berkompromi dengan kondisi hipoksia dan hipoglikemia, yang menyebabkan disfungsi seluler, hingga akhirnya sampai terjadi kematian sel. ${ }^{3}$ 
Jurnal Kardiologi Indonesia

\section{Peran Radikal Bebas pada Iskemia Miokard}

Radikal bebas adalah spesies yang memiliki satu atau lebih elektron yang tidak berpasangan. Konfigurasi ini menyebabkan peningkatan reaktivitas dengan molekul lain. ${ }^{11}$ Semula, kata "bebas" digunakan oleh ahli kimia untuk membedakan antara $\mathrm{R}^{\bullet}$ dan $\mathrm{R}^{\bullet}-\mathrm{X}^{\bullet}, \mathrm{R}^{\bullet}$ sebagai "radikal" dan $\mathrm{R}^{\bullet}$ pada $\mathrm{R}^{\bullet}-\mathrm{X}^{\bullet}$ sebagai "radikal” yang terikat. Sehingga dalam definisi sederhana, radikal bebas juga diartikan sebagai semua atom (mis. oksigen, nitrogen) atau kelompok atom atau spesies molekul yang mampu secara bebas mengandung setidaknya satu atau lebih elektron yang tidak berpasangan pada konfigurasi lapisan terluarnya.

Banyak jenis radikal bebas yang diketahui, diantaranya radikal bebas yang melibatkan oksigen yang disebut spesies oksigen reaktif (reactive oxygen species/ ROS), anion superoksida $\left(\mathrm{O}_{2}^{-\bullet}\right)$, radikal hidroksil $\left(\mathrm{OH}^{\bullet}\right)$ suatu bentuk netral ion hidroksil, radikal peroksil $\left(\mathrm{RO}_{2} \cdot\right)$ dan alkoksil $(\mathrm{RO} \cdot)$, lipid peroxidation (LPO), radikal askorbat $\left(\mathrm{A}^{\bullet}\right)$, singlet oxygen $\left({ }^{1} \mathrm{O}_{2}\right)$, ozone $\left(\mathrm{O}_{3}\right)$, hidrogen peroksida $\left(\mathrm{H}_{2} \mathrm{O}_{2}\right)$, dan spesies nitrogen reaktif (reactive nitrogen species/RNS) seperti radikal nitrik oksida $(\mathrm{NO} \bullet) .{ }^{12} 13$

Dalam miokardium, reduksi oksigen menjadi air, terjadi melalui dua jalur : (1) Sitokrom oksidase mitokondria yang mereduksi $95 \%$ oksigen menjadi air dengan pengurangan tetravalen tanpa ada produksi lain diantaranya; (2) Sisanya sebesar 5\% oksigen melalui jalur univalen, menghasilkan produk antara, seperti anion superoksida $\left(\mathrm{O}_{2}^{-\bullet}\right)$, hidrogen peroksida $\left(\mathrm{H}_{2} \mathrm{O}_{2}\right)$, dan radikal hidroksil $(\cdot \mathrm{OH})$. Tanda titik $\left(^{\bullet}\right)$ merupakan sebuah elektron tidak berpasangan dan menandakan suatu radikal bebas. ${ }^{1,11}$ Selain itu juga dihasilkan serangkaian mekanisme pertahanan berupa enzim superoksida dismutase, katalase dan glutation peroksidase, serta antioksidan endogen lain seperti vitamin E, asam askorbat, dan sistein. Sehingga miokardium aerobik mampu menangani dan tetap bertahan ketika radikal bebas diproduksi secara fisiologis karena terdapat keseimbangan antara berbagai oksidan dan antioksidan sebagai mekanisme pertahanan yang dihasilkan di dalam sistem seluler. ${ }^{1,14,15}$

Selama iskemia, oksigen yang tersedia hanya sedikit atau bisa tidak ada sama sekali. Tetapi bukan berarti radikal bebas oksigen tidak bisa dibentuk. ${ }^{1}$ Oksigen radikal dibentuk oleh miosit yang mengalami injuri dan sel-sel endotelial pada zona iskemia, juga neutrofil yang masuk ke zona tersebut, yang menjadi aktif ketika terjadi reperfusi. Oksigen radikal tersebut memperburuk kerusakan membran dan menyebabkan masuknya kalsium ke dalam sel. Neutrofil akan menumpuk di mikrosirkulasi, mengeluarkan mediator inflamasi, dan berkontribusi terhadap obstruksi mikrovaskuler dan fenomena no-reflow dalam reperfusi miokardium. Ada banyak sumber yang memproduksi radikal bebas dalam miokardium. Radikal bebas dapat berasal dari metabolisme asam arakidonat dan katekolamin, metabolisme nukleotida adenin oleh xantin oksidase di endothelium (tergantung spesiesnya), dan aktivasi neutrofil dan makrofag. ${ }^{9}$ Sulit untuk menentukan sumber mana yang paling penting. Oksigen sumber radikal bebas dapat dihasilkan dari tempat yang berbeda setelah periode iskemia atau reperfusi. Ketika terjadi reperfusi, setelah periode singkat iskemia, hanya satu atau dua sumber radikal bebas yang terlibat. Tetapi jika reperfusi tertunda lama, maka sumber radikal bebas lain dapat menjadi sumber penting dalam menghasilkan $\mathrm{O}_{2}$ radikal. ${ }^{11,16}$

Ada beberapa sumber radikal bebas pada miosit selama iskemia dan reperfusi, namun sumber yang paling penting adalah mitokondria. ${ }^{1}$ Pada saat respirasi, electron transport chain (ETC) kompleks I dan III di mitokondria akan menghasilkan sejumlah kecil ROS, terutama anion superoksida $\left(\mathrm{O}_{2}^{-\bullet}\right)$. Anion tersebut secara cepat akan dirubah menjadi hidrogen peroksida $\left(\mathrm{H}_{2} \mathrm{O}_{2}\right)$ oleh enzim metallo dan superoksida dismutase (SOD). Pada kondisi stres seluler, khususnya stres oksidatif pada iskemia, respirasi melalui sitokrom oksidase pada subsarkolema mitokondria (SSM) akan menurun. Terjadi blokade kompleks I dan III di ETC yang akan menurunkan produksi ROS selama episode iskemia dan melindungi mitokondria dari kerusakan akibat iskemia. Namun ketika blokade terjadi pada bagian distal ETC kompleks III bagian distal (di bagian sitokrom c oksidase) maka terjadi peningkatan produksi ROS. Aksi ROS dapat merusak komponen membran mitokondria (lemak dan protein) dan DNA mitokondria (mtDNA), pembukaan mPTP, sehingga terjadi depolarisasi mitokondria, hilangnya sitokrom c, dan apoptosis. ${ }^{17,} 18$ Selama reperfusi, kerusakan iskemik pada ETC menyebabkan peningkatan $\mathrm{O}_{2}^{-}$ dan $\mathrm{H}_{2} \mathrm{O}_{2}$. Mitokondria juga menghasilkan spesies oksigen reaktif, seperti radikal hidroksil $(\mathrm{OH})$ yang menyebabkan bertambahnya cedera mitokondria dan miosit. Pembentukan $\mathrm{OH}$ tersebut dapat diamati menggunakan teknik ESR (electron spin resonance) trapping dan teknik salisilat hidroksilasi. ${ }^{19}$ Kenaikan kalsium pada mitokondria akan meningkatkan 
produksi ROS dan mengurangi kapasitas antioksidan mitokondria dengan menurunnya aktivitas SOD dan konsentrasi glutation peroksidase, yang merupakan sumber utama detoksifikasi terhadap $\mathrm{H}_{2} \mathrm{O}_{2}$. 7 , 18 , 19 Semua proses tersebut dapat merusak struktur miokard sehingga terjadi kondisi kardiomiopati yang mengganggu fungsi jantung. ${ }^{18}$

\section{Kesimpulan}

Iskemia miokard dan injuri reperfusi merupakan kondisi yang dapat menimbulkan kerusakan dan tidak berfungsinya jaringan jantung. Masalah yang ditimbulkan oleh iskemia miokard tidak homogen dan melibatkan banyak faktor, karena terjadi serangkaian perubahan metabolik, elektrik, histologi, struktural, dan fisiologis. Perubahan metabolisme sel miosit akibat iskemia dan peran radikal bebas perlu dipahami lebih dalam dan diteliti lebih lanjut agar dapat memperbaiki strategi terapi penderita iskemia miokard sehingga mencegah kerusakan jantung lebih lanjut.

\section{Daftar Pustaka}

1. Ferrari R, Pepi P, Ferrari F, Nesta F, Benigno M, Visioli O. Metabolic Derangement in Ischemic Heart Disease and Its Therapeutic Control. Am J Cardiol 1998;82:2K-13K.

2. Frank A, Bonney M, Bonney S, Weitzel L, Koeppen M, Eckle T. Myocardial Ischemia Reperfusion Injury: From Basic Science to Clinical Bedside. Seminars in Cardiothoracic and Vascular Anesthesia. 2012;16(3):123-132.

3. Kutala VK, Khan M, Angelos MG, Kuppusamy P. Role of Oxygen in Postischemic Myocardial Injury. Antioxidants \& Redox Signaling. 2007;9(8):1193-1206.

4. Jennings RB, Reimer KA. Lethal Myocardial Ischemic Injury. AmJ Pathol. 1981;102:241-255.

5. Bainey KR, Armstrong PW, Alberta. Clinical perspectives on reperfusion injury in acute myocardial infarction. Am Heart J 2014;0:1-9.

6. Jennings RB. Historical Perspective on the Pathology of Myo- cardial Ischemia/Reperfusion Injury. Circ Res. 2013;113:428438.

7. Gourdin M, Dubois P. Impact of Ischemia on Cellular Metabolism. In: Aronow WS, ed. Artery Bypass. Belgium: InTech; 2013.

8. Buja LM. Coronary Artery Disease: Pathological Anatomy and Pathogenesis. In: Willerson JT, Jr DRH, eds. Coronary Artery Disease. London: Springer London; 2015:1-20.

9. Buja LM. Myocardial ischemia and reperfusion injury. Cardiovascular Pathology 2005;14:170- 175.

10. Yellon DM, Downey JM. Preconditioning the Myocardium : From Cellular Physiology to Clinical Cardiology. Physiol Rev 2003;83:1113-1151.

11. Ferrari R, Ceconi C, Curello S, Alfierii O, Visioli O. Myocardial damage during ischaemia and reperfusion. European Heart Journal. 1993;14 (Supplement G):25-30.

12. Gutowski M, Kowalczyk S. A study of free radical chemistry: their role and pathophysiological significance. Acta Biochimica Polonica. 2013;60(1):1-16.

13. Young CP, Williams BT. Free radicals and myocardial injury. Pakistan Heart Journal. 1990;23(2):27-33.

14. Shah AM, Channon KM. Free radicals and redox signalling in cardiovascular disease. Heart. 2004;90:486-487.

15. Hearse DJ. Free radicals and myocardial injury during ischemia and reperfusion : a short-lived phenomenon In: Rosen MR, Palti Y, eds. Lethal arrhythmias resulting from myocardial ischemia and infarction. Boston/Dordrecht/London: Kluwers Academic Publisher; 1989:105-115.

16. Ferrari R. Oxygen free radicals at myocardial level : Effects of ischaemia and reperfusion. In: Armstrong D, ed. Free Radicals in Diagnostic Medicine. New York: Plenum Press; 1994:99-111.

17. Lisa FD, Bernardi P. Mitochondria and ischemia-reperfusion injury of the heart: Fixing a hole. Cardiovascular Research 2006;70:191 - 199 .

18. Stride N, Larsen S, Hey-Mogensen M, Hansen CN, Prats C, Steinbrüchel D. Impaired mitochondrial function in chronically ischemic human heart. Am J Physiol Heart Circ Physiol. 2013;304:H1407-H1414.

19. Lesnefsky EJ, Moghaddas S, Tandler B, Kerner J, Hoppel CL. Mitochondrial Dysfunction in Cardiac Disease: IschemiaReperfusion, Aging, and Heart Failure. J Mol Cell Cardiol 2001;33:1065-1089. 